\title{
전자조달시스템 \\ 기능고도화 구축현황
}

한국국제협력단(KOICA)은 국민과 함께하는 선진원조를 집행하고자 관련업무 전반의 표준화 - 정 보화를 구축하고 있습니다. 이러한 노력의 일환으로 대외원조사업 조달분야를 위한 '전자조달시 스템 기능고도화 를 2007년 1월에 구축했고, 이를 바탕으로 대외원조사업관련 조달업무 전 분야 를 전산화하여 전자조달 시스템을 선도적으로 운영하고 있습니다. 지난 200 여일간 추진하였던 전자조달시스템 기능고도화사업은 기능과 사용자 편의성을 중심으로 기존 KOICA 전자조달시스 템을 새롭게 개편하였고, 400 여개 이상의 조달 협력업체 - 기관, $\mathrm{KOICA}$ 전부서 및 해외사무소에 서 조달관련 업무를 원활히 사용할 수 있게 되었습니다. 시스템의 주요 사항을 소개하면 다음과 같 습니다.

\section{1. 사업 개요}

- 사 업 명 : 전자조달시스템 기능고도화 구축 (http://ebid.koica.go.kr)

- 사업기간 : '06년 7월 3일 '07년 1월 12일

\section{1) 구축내용}

"대외무상원조사업관련 조달분야 전 과정에 대한 인터넷 기반의 온라인 One-Stop 조달 업무 처리 시스템"

- 한국국제협력단의 전자조달 시스템은 대외무상 협력사업의 입찰, 계약, 검수 및 대금청구, 물류 까지의 모든 조달업무 프로세스를 전산화하여 보 다 투명하고 신뢰도 높은 조달업무수행을 도모 
2) 기대효과

- 국제협력사업 전담기관으로서 전문화된 조 달업무 혁신가치 확대

- 전자조달시스템을 통한 조달업무의 공정성 및 효율성 강화

- 내· 외부시스템과의 원활한 연계를 통한 유 기적인 통합 조달 시스템 완성

- 보안강화를 통해 조달정보보호에 적극 대응 (외부해킹 대비 등)

3) 전자조달시스템 사용자

\begin{tabular}{l|l}
\hline \multicolumn{1}{c|}{ 업 무 } & \multicolumn{1}{c}{ 관련부서 } \\
\hline $\begin{array}{l}\text { 조달업무 진행상황 및 } \\
\text { 입찰결과, 물류정보 }\end{array}$ & $\begin{array}{l}\text { 조달팀, 조달의뢰부서, } \\
\text { 해외사무소(26개) }\end{array}$ \\
\hline $\begin{array}{l}\text { 일반입찰 및 계약업무 } \\
\text { (연수계약 포함) }\end{array}$ & KOICA 소 부서 \\
\hline 입찰참가 및 계약체결, \\
대금청구
\end{tabular}

\section{4) 구축 범위}

- 운영시스템 개선

- 전자입찰 - 계약 시스템 기능 개선

- 통계 및 출력 기능 개선

- 신규시스템 개발

- 검수, 물류관리

- 역경매 / 자산매각 입찰

- 전자결재 / 조달팀내부결재

- 전자세금계산서

- 전자카탈로그 / 계약상품관리
- SMS알림서비스

- 입찰방법의 다양화

- 협력업체 실적증명원

- 자동차회사 견적등록관리

- 내·외부 시스템 연계 및 통합

- KOIMS 내부시스템 연계

- 조달청(G2B)을 통한 외부 시스템 연계

(입찰공고 / 낙찰결과, 보증보험기관, 신용평 가기관의 입찰참가업체 신용등급)

- 시스템 보안 기능강화

- 키보드 보안 솔루션 도입 및 적용

- 업체담합 방지를 위한 IP보안

- 총체적인 보안대책 및 보안 감리

\section{2. 전자조달시스템 안내}

\section{1) 시스템 안내}

전자조달시스템 주요 사용자는 국제협력단 내부사 용자, 조달 및 일반 협력업체·기관 담당자, 조달 팀 담당자이며 동 시스템이 연계되는 외부기관으 로서는 조달청 ‘ $\mathrm{G} 2 \mathrm{~B}$ (나라장터)시스템', 신용평가 기관, 보증보험기관이 있음. 조달청 ' $\mathrm{G} 2 \mathrm{~B}$ '를 통해 입찰공고 및 낙찰결과를 연계 처리하며, 신용평가 기관 및 보증보험기관을 통해 기업의 신용등급정 보와 보증보험정보를 연계 처리함. 
2) 전자조달 기능고도화 추진에 대한 기대효과

\begin{tabular}{c|l}
\hline \hline 분 야 & \multicolumn{1}{c}{ 주 요 내 용 } \\
\hline \hline \multirow{3}{*}{ 직접적인 성과 } & - 통계 및 출력 기능 강화를 통한 인지세 및 문서 보관의 비용절감 \\
& - SMS메시지, 이메일 발송을 통한 계약업체의 편의성 증대 \\
& - 물품구입시 역경매 입찰 도입을 통한 비용최적 효과 \\
& - 물류관리 및 선적서류의 온라인화를 통한 체계적인 물류 모니터링 \\
\hline & - 구매업무처리 절차 간소화 및 업무량, 업무시간 단축 \\
& - 세금계산서 기능 도입을 통한 세무업무의 간소화 \\
\hline \multirow{5}{*}{ 업무 효율성 } & - 조달의뢰 요청 기능 개선으로 업무 처리의 일원화 \\
& - 신용평가 기관과의 연계를 통한 실시간 협력업체 신용정보 확인 \\
& - 입찰 및 계약 방법의 다양화를 통한 조달 업무의 유연성 확대 \\
\hline \multirow{5}{*}{ 서비스 향상 } & - 전자입찰정보에 대한 보안성 강화하여 협력업체의 입찰정보 누출방지 \\
& - G2B 보증보험 온라인 연계를 통한 협력업체의 비용 및 시간 감소 \\
& - 대금청구 및 세금계산서 기능을 통한 대금청구 프로세스의 간소화 \\
& - 온라인 도움말을 통한 대고객 서비스 향상 및 만족도 개선 \\
& - 업무 역할에 맞는 MY PAGE 구성을 통한 입찰 업무의 편의성 증대 \\
\hline
\end{tabular}

\section{3. 안정적 정착 계획}

- 지속적인 학습 및 홍보

- 사용자 매뉴얼 배포 (내부사용자, 협력업체

및 기관)

- 팀 · 부서별 방문 맞춤식 교육 등 다양한 방

식의 교육 실시
- 사용실적 및 조달추진 현황 등 주기적 점검

- 조달품목 및 계약물품에 대한 $\mathrm{DB}$ 의 주기적 업 데이트

- 전자조달시스템 개발기술자의 상주 유지보수 계약체결( '07.4월)

※ 향후 KOICA 전자조달시스템은 내부적으로는 통합원조관리시스템(KOMIS)과, 외부적으로는 조달청 나라장터(G2B)와 연계된 시스템 구조를 가지게 될 것이고 이는 대외무상원조사업과 관련된 모든 계약 및 조달 업무 정보의 공유- 발전을 의미합니다. 동 시스템의 체 계적 발전을 위해서는 시스템 교육, 사용자 불편해소 등의 자체적인 변화 및 관리 노력과 함께 대내외적 협조가 필요할 것입니다. 
전자조달시스템 구성도

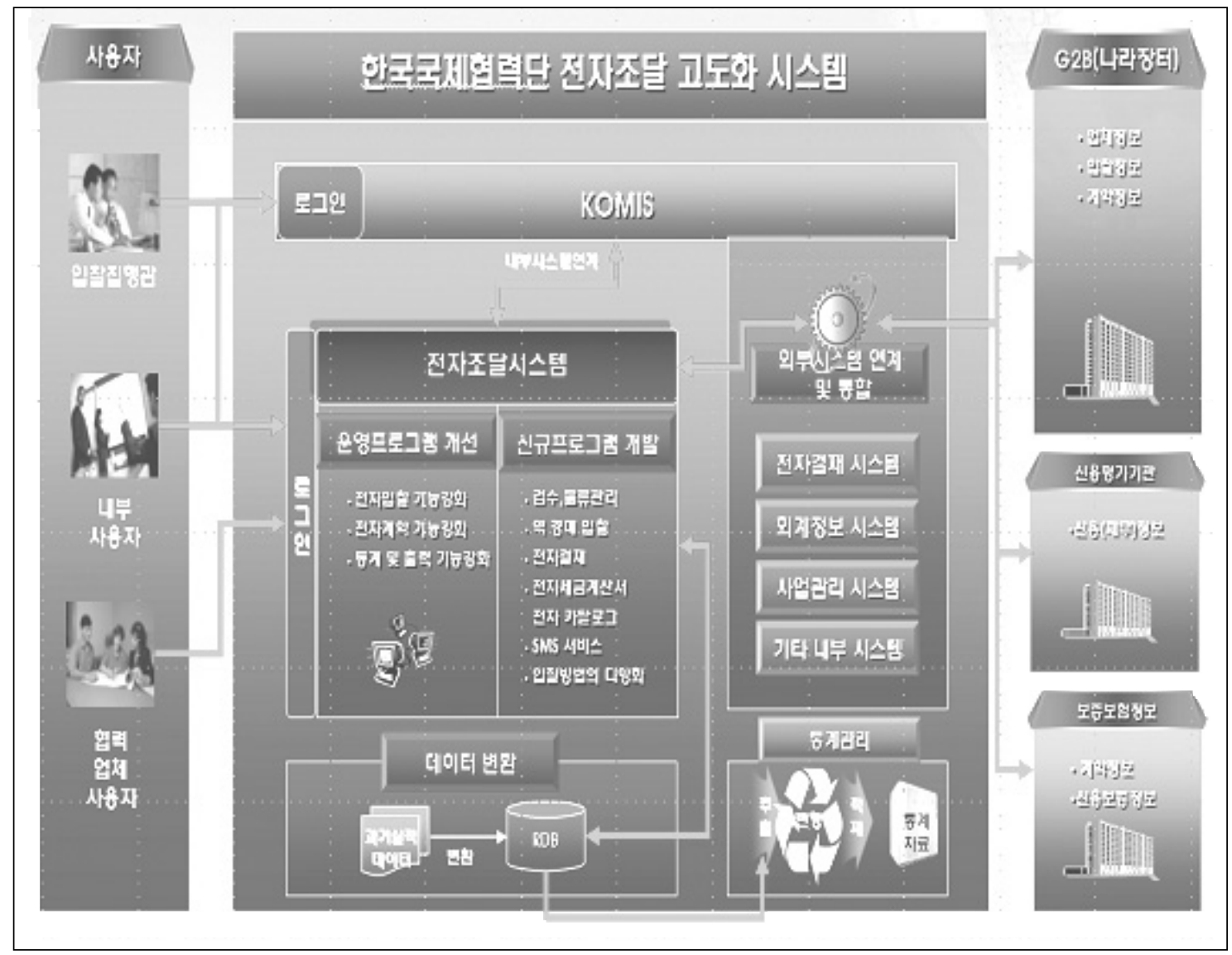

